\title{
KOPIEC WYZWOLENIA. GENEZA, HISTORIA, SYMBOL TOŻSAMOŚCI
}

Idea wybudowania w Piekarach ${ }^{1}$ koło Bytomia, w znanym miejscu pielgrzymkowym na Górnym Śląsku, niezwykłego pomnika, symbolu niepodległości i przynależności tych ziem do Polski oraz znaku trwania Górnoślązaków przy uniwersalnych wartościach religijnych i narodowych, ma długą i zawiłą historię. Samorodny pisarz śląski Wawrzyniec Hajda zaapelował w 1883 roku do mieszkańców Piekar i okolicy, aby godnie uczcili 200 rocznicę bitwy pod Wiedniem ${ }^{2}$, podczas której geniusz wojenny polskiego króla Jana III Sobieskiego ocalił chrześcijańską cywilizacje Europy przed wojskami tureckimi Kara Mustafy. Przed bitwa, 20 sierpnia 1683 roku król polski wraz z wieloma dostojnikami państwowymi i dowódcami wojskowymi oraz żołnierzami modlił się przed wierną kopią cudami słynącego obrazu Matki Bożej w Piekarach o błogosławieństwo dla wyprawy ${ }^{3}$. Przesłanki te skłoniły właśnie Wawrzyńca Hajdę do publicznego wystąpienia, w którym zachęcał do usypania słowiańskim zwyczajem kopca $w$ miejscu położonym niezbyt daleko od budującej się Kalwarii w Wielkich Piekarach na Wzgórzu Cerekwicy ${ }^{4}$.

Kim był Wawrzyniec Hajda? Na pruskim Śląsku w dramatycznym dla sprawy Polski XIX wieku, w najgorszych warunkach socjalnych ${ }^{5}$, kulturowych

${ }^{1}$ Warto uświadomić sobie, że dzisiejsza miejscowość Piekary Śląskie miała poprzednio różne nazwy; w 1136 r. - prawdopodobnie Zwersow; od 1227 r. Peccare, w 1332 r. - Peccari Theuttonicale [Piekary Niemieckie], 1369 r. - Polnische Beckem, 1420 r. - Gross Beckern, od XVII w. Deutsch Piekar, 1932 r. Piekary Wielkie, 1934 r. Szarlej - Piekary, 1935 r. - Piekary Ślaskie.

${ }^{2}$ F. H a w ra n e k, Kopiec Wyzwolenia w Piekarach Ślaskich [w:] Encyklopedia Powstań Ślaskich, red. F. H a w r a n e k, A. K w i a t e k, W. L e s i u k i in., Opole 1982, s. 239 n.

${ }^{3}$ Król polski Jan III Sobieski w Piekarach (dnia 20. sierpnia 1683 r) [w:] Piekary. Pamiqutka koronacji cudownego obrazu Matki Boskiej Piekarskiej, która się odbyła dnia 15-go sierpnia 1925 roku, [pod. red. E. S z r a m k a ] Piekary 1926, s. 48-55.

${ }^{4}$ Obecnie mieści się tam Szkoła Podstawowa nr 4.

${ }^{5} \mathrm{~K}$. J o ń c a, Potożenie robotników w przemyśle górniczo - hutniczym na Ślqsku w latach 1889-1914, Wrocław 1960, passim; Z. L e s z c z y n s k i, Zagrożenia zawodowe a medycyna fabryczna na ziemiach polskich na przetomie XLX-XX wieku, Warszawa 1986; F. C hła - 
i politycznych, a więc w nędzy i w pogardzie ${ }^{6}$ dojrzewały jednostki, samorodne, zdolne do wypracowania oryginalnych programów działań społeczno-religijnych i narodowych? ${ }^{7}$ Wyrastały w środowisku ludzi ciężkiej pracy. Niespotykany w innych regionach Polski, a charakterystyczny dla Śląska nowoczesny robotnik cechował się tym, że chociaż miał wykształcenie zawodowe i parał się pracą zarobkową $z$ trudem utrzymując rodzinę ${ }^{8}$, był jednak świadomy swego miejsca w społeczeństwie. Mimo nie sprzyjających warunków, zmęczony nadludzką pracą fizyczną potrafił się nastawić na tworzenie dobra wspólnego, które polega na stworzeniu maksymalnych szans rozwojowych osobom przynależnym do różnych społeczności. Miało ono obejmować wszystkie warunki życia społecznego, w jakich można pełniej i szybciej osiagnąc własną doskonałość 9 .

Typowym przedstawicielem wąskiej grypy ludzi pracy - samouków z Górnego Śląska, dążących do uświadomienia narodowego mieszkańców tego regionu i przyłączenia tego regionu do Polski, po prawie sześciu wiekach niewoli, po uprzednim odrodzeniu religijno-moralnym społeczeństwa jest Wawrzyniec Hajda ${ }^{10}$. Uosabiał on wszystko to, co faktycznie - przez 80 lat - składało się na niepowtarzalność Górnego Śląska na przełomie XIX i XX wieku; z tego też względu już za życia określano go mianem ,śląskiego Wernyhory" ${ }^{11}$. Podobnie bowiem, jak ów ukraiński Kozak, śpiewak ludowy i lirnik, przeciwnik hajdamaczyzny, a tym samym przemocy i rozlewu krwi, zwolennik dialogu i porozumienia z narodowymi sąsiadami przepowiadajacy przyszłe losy Polski na podstawie ówczesnych wydarzeń historycznych, zwiastun lepszej doli, szczególnie uwolnienia społeczeństwa $z$ różnych zniewolen ${ }^{12}$, wierzył -- darząc ogromną miłością swą Ojczyznę - w ,zmartwychwstanie Polski”,13. Idee religijno - moralne $\mathrm{i}$ narodowe głoszone przez ociemniałego, charyzmatycznego działacza społeczno - religijnego Hajdę wśród prawie bezgranicznie oddanej mu młodzieży, wychowywanej w duchu surowych zasad etyczno-moralnych, miały przygotować młode pokolenie Polaków do stworzenia stosunków społecznych

p ow ski, Hygiena rzemiost, czyli o szkodliwych wptywach każdemu zawodowi właściwych $i$ sposobach zapobieżenia tymże, Bytom 1876.

${ }^{6}$ E. K a c z y ń s k a, Dzieje robotników przemystowych w Polsce, Warszawa 1970; Taż, Potożenie klasy robotniczej, [w:] Polska klasa robotnicza. Zarys dziejów, t. 1, cz. 2. Warszawa 1978; S. M i c h al k i e w i c z, Przemyst i robotnicy na Ślasku (do 1914 roku), Katowice 1984.

${ }^{7}$ Można do nich zaliczyć - oprócz W. Hajdy - przede wszystkim: J. Lompe, J. Kopca, J. Ligonia, J. Gajdę, M. Jasionowskiego

${ }^{8}$ Zob. Slascy pisarze ludowi (1800-1914). Antologia poezji i prozy. Wyboru dokonała i opracowała J. K u c i a n k a, Wroclaw-Warszawa-Kraków 1986.

${ }^{9}$ Współczesne brzmienie zasady dobra wspólnego zawarte jest m.in. w encyklikach spolecznych J a n a XXIII Mater et magistra $\mathrm{nr} 65$ i Pacem in terris $\mathrm{nr} 58$.

${ }^{10} \mathrm{~J}$. W y c i s to, Zasada pierwszeństwa odrodzenia religijno-moralnego przed narodowym, czyli dziatalność religijno - spoteczna Wawrzyńca Hajdy, [w:] J. W y c i sło, W kręu sanktuarium maryjnego w Piekarach Ślaskich, Katowice 1997, s. 61-116.

${ }^{11}$ K. Ż y d e k, Wernyhora z Piekar, „Katolik”1985 nr 11 z dn. 17.03 .

${ }^{12}$ W. S t a b r y ł a, Wernyhora w literaturze polskiej, Kraków 1996, s. 13 n.

${ }^{13} \mathrm{~S}$. W a $1 \mathrm{l}$ is, Wawrzyniec Hajda - Wernyhora Slaski (Szkic biograficzny), Chorzów 1945, Muzeum Miejskie w Chorzowie, ms., bez sygn. 
opartych na wartościach religijnych i patriotycznych. Podkreślała to niezmiennie ówczesna prasa polska ${ }^{14}$.

Oryginalny pomysł budowy Kopca w Piekarach Wielkich, chociaż znacznie wykraczał poza ramy „zwykłej” działalności Hajdy, na tle wielu jego pragmatycznych działań nie dziwił. Niestety, projekt Śląskiego Wernyhory spotkał się z dezaprobatą władz pruskich, które upatrywały w nim zagrożenie dla wschodniej polityki Niemiec, zmierzającej do eliminacji tzw. elementów słowiańskich. Dlatego landrat bytomski, następca osławionego Karla Ernsta Wilhelma Solgera, kategorycznie odmówił Hajdzie realizacji projektu. Mimo to Wawrzyniec Hajda nie zrezygnował ze swej idei. W ciagu najbliższych kilku lat aż trzykrotnie przystępował z liczną grupą młodzieży i działaczami społecznokatolickimi do prac przygotowawczych przy wznoszeniu kopca ${ }^{15}$.

Mieszkańcy Piekar Wielkich, znani z aktywności społeczno-narodowej i religijnej, a szczególnie najbliżsi współpracownicy Hajdy, do tego projektu mieli jeszcze powracać kilkakrotnie ${ }^{16}$. Okazji było sporo, ponieważ znaczących wydarzeń historycznych i religijnych na Górnym Śląsku w pierwszych dekadach $\mathrm{XX}$ wieku było wiele. $\mathrm{Na}$ decydujące dla dalszych planów budowy kopca należało jednak czekać prawie 50 lat $^{17}$.

20 sierpnia 1930 roku w restauracji - zajeździe Głazowskiego przy ulicy Kalwaryjskiej w Piekarach Wielkich odbywało się zebranie byłych powstańców śląskich, którzy obchodzili 10 rocznicę wybuchu drugiego zrywu zbrojnego, mającego na celu przyłączenie Górnego Śląska do Polski. Jednym z zaproszonych gości był komendant lwowskiego korpusu kadetów pułkownik Lorek ${ }^{18}$. Po części oficjalnej, poświęconej wspomnieniom walk powstańczych, zastanawiano się nad różnymi formami upamiętnienia trzech kolejnych powstań śląskich. Wówczas dawny obrońca hotelu „Lomnitz” w Bytomiu, były dowódca oddziałów powstańczych w powiecie toszecko-gliwickim i zabrskim, pracujący w redakcjach „Polaka” i „Polski Zachodniej” korespondent Stanisław Mastalerz przypomniał ciagle aktualny w Wielkich Piekarach projekt Wawrzyńca Hajdy dotyczacy usypania kopca-pomnika ${ }^{19}$. Realizacja tego pomysłu spotkała się

${ }^{14}$ Np. „Katolik Niedzielny” 1923 nr 13; „Glos z nad [!] Brynicy” 1925, nr 1; „Polonia” 1927, nr 176; „Urzędnik Polski” 1927, nr 9/10; „Gość Niedzielny” 1945, nr 29.

${ }^{15}$ M.in. $\mathrm{z}$ tego powodu wytoczono mu proces w sądzie bytomskim, z którego jednak wyszedł uniewinniony. Kalectwo Hajdy, wzbudziło litość członków kolegium sędziowskiego. Postać ślepego starca, powłóczącego niezgrabnie nogami i prowadzonego przez uczniów oraz licznych przyjaciół, przypuszczalnie sprawiła wówczas przejmujące wrażenie.

${ }^{16}$ Najbliższymi współpracownikami W. Hajdy byli: Karol Cisek, Franciszek Gracek, Józef Kałdonek, Jan Ludyga, Franciszek Polak, Augustyn Głazowski, Jan Stasiak, oraz Jan, Józef i Paweł Millerowie.

17 „Polska Zachodnia” [ dalej: PZ] 1932, nr 239.

18 PZ 1937, nr 167. Więcej na temat wizyty kadetów w Piekarach traktuje artykuł pt. Lwowiacy w Piekarach [w:] Z tej ziemi. Ślaski kalendarz katolicki na rok 1993, Katowice 1992, s. $85-90$.

${ }^{19} \mathrm{PZ} 1937 \mathrm{nr} 167 \mathrm{z}$ dn. 20. 06. Hasła nt. Kopca Wyzwolenia w Piekarach Ślaskach brak w najnowszej Encyklopedii Historii Drugiej Rzeczypospolitej, [red. nauk. A. Garlicki, Z. Landau, W. Roszkowski, P. Stawe ck i, J. Tomaszew ski], Warszawa 1999. 
z pełną aprobatą uczestników zebrania ${ }^{20}$. Po powrocie do Lwowa o projekcie usypania kopca przypomniał innym kadetom płk Lorek ${ }^{21}$.

Na wiosne 1932 roku w Piekarach Wielkich zawiązał się [Społeczny] Komitet Obchodu 250. rocznicy zwycięskiej bitwy pod Wiedniem i pobytu króla polskiego Jana III Sobieskiego w sanktuarium maryjnym, która przypadała 20 sierpnia 1933 roku. W skład Komitetu wchodzili: starosta powiatu swiętochłowickiego T. Szaliński, ks. prałat W. Pucher i naczelnik gminy Piekary Jan Pudlik $^{22}$. W czasie dyskusji nad sposobem uczczenia tej tak ważnej rocznicy znów przypomniano idę̨ Wawrzyńca Hajdy. Niezależnie od tego ze Lwowa dotarł do Wielkich Piekar apel pułkownika Lorka, przynaglający rodaków do realizacji decyzji powziętej przed dwoma laty na zebraniu byłych powstańców śląskich z lwowskimi kadetami.

Ale i tym razem na przeszkodzie szybkiej realizacji pomysłu stanęły watpliwości związane z usytuowaniem kopca. Część organizatorów przedsięwzięcia opowiadała się za tym, aby kopiec usypać za kalwarią piekarską, a więc tam, gdzie proponował Hajda. Inni zainteresowani upatrywali lokalizację kopca w pobliskiej miejscowości Kozłowa Góra. Jeszcze inni wskazywali na miejsce po dawnej kopalni węgla kamiennego „Scharley”. Natomiast zastępca starosty świętochłowickiego Wiktor Polak proponował usypanie kopca na tzw. Kocich Górkach, sugerując, że jest to odsłonięty obszar leżący na wysokości $333 \mathrm{~m}$ n.p.m., zapewniający dobrą widoczność i mający swoją historię. Tutaj bowiem bytomscy powstańcy składali przysięge przed wymarszem na III powstanie śląskie. Na Kocich Górkach w końcu XIX wieku odbywały się także ćwiczenia piekarskiego i szarlejskiego gniazda Towarzystwa Gimnastycznego „Sokół” organizacji znanej z patriotycznego wychowania młodzieży. Stąd rozciagał się widok na Bytom i okolicę, „,co miało przypominać Polakom na Śląsku Opolskim, że Polska pamięta o rodakach zza kordonu granicznego"23. Wreszcie - jak thumaczył Wiktor Polak - na tym miejscu zginą jeden z pierwszych powstańców piekarskich. Wywody te przekonały zainteresowanych. Powołano więc Komitet Budowy Kopca. Jego przewodniczącym został były dowódca batalionu powstańców z Rozbarku Jan Lorc, funkcję sekretarza powierzono wspomnianemu już Stanisławowi Mastalerzowi. Pozostałymi członkami zarządu zostali: starosta powiatu świętochłowickiego Tadeusz Szaliński, jego zastępca Wiktor Polak, naczelnik gminy Piekary Wielkie Jan Pudlik oraz działacze Zwiazku Powstańców Śląskich - Rudolf Kornke i Jan Przybytek. W obradach Komitetu uczestniczył także ks. W. Pucher, proboszcz z Wielkich Piekar ${ }^{24}$.

${ }^{20}$ Potem poparli ją mieszkańcy Piekar. Panowała zgoda co do tego, że słynna miejscowość pielgrzymkowa, szczycąca się kościołem mariackim z cudownym obrazem Matki Bożej, właśnie w taki sposób powinna uczcić znaczące wydarzenia w historii Gómnego Śląska i Polski, a także w historii Kościoła diecezjalnego.

${ }^{21}$ Najstarsi z nich w maju 1921 r. walczyli w powstaniu na Górnym Śląsku.

${ }^{22} \mathrm{PZ} 1932$, nז 253.

${ }^{23}$ [W. P o l a k ?] Spetnity się sny pokolen,, Muzeum Miejskie w Chorzowie, ms., bez sygn.

${ }^{24} \mathrm{PZ} 1932 \mathrm{nr} 253$. 
Równocześnie powołano „Komitet Honorowy, do którego wybrano wiele wybitnych osobistości'”25. Zaczęto także realizować koncepcję utworzenia tzw. Protektoratu czuwającego nad wznoszeniem kopca, któremu miano nadać nazwę „Kopca Wyzwolenia Śląska”. Zespół protektorów miał się składać z wysokich osobistości państwowych i duchownych. Najważniejszym organem pozostał nadal honorowy Komitet Budowy Kopca. W jego skład weszli m.in.: generałowie Kazimierz Fabrycy i Felicjan Sławoj-Składkowski, pułkownik Kompanii Korpusu Kadetów Florek oraz duchowni - ks. [N.] Gąbowski z Wilna i proboszcz piekarski Wawrzyniec Pucher, a także major Bombas ze Lwowa oraz minister Janusz Jędrzejewski. Do zadań wspomnianego Komitetu należało nadawanie odpowiedniego prestiżu społeczno-narodowego i religijnego wznoszeniu Kopca oraz propagowanie idei budowy pomnika-symbolu. Czas budowy określono na kilka lat.

Po potwierdzeniu, że teren na Kocich Górkach nie jest objęty eksportacją górniczą Komitet Budowy „Kopca Wyzwolenia Ślaska”, który od połowy maja 1933 r. nosił nazwę Komitet Budowy „Kopca Wyzwolenia”, rozpoczął uciażliwe zabiegi o kupno ziemi należącej do hrabiego Henckla von Donnersmarcka, znanego z poglądów proniemieckich. Pruski junkier zrazu odmówił sprzedaży ziemi, później jednak zmienił zdanie, żądając za 3 hektary nieużytków kwoty sięgającej 12 tysięcy złotych ${ }^{26}$. Ponieważ Komitet dysponował tylko połową żadanej kwoty ${ }^{27}$, pertraktacje przeciagały się. Hrabia był nieustępliwy, zamierzał bowiem nie dopuścić do budowy kopca. Na wieść o wygórowanych żądaniach hrabiego, mimo trwającego kryzysu ekonomicznego, społeczeństwo ziemi tarnogórskiej, wespół z licznie przybywającymi do Piekar Wielkich pielgrzymami, zdołało jednak zebrać wyznaczoną sumę pieniędzy. Transakcja doszła do skutku we wrześniu 1932 roku. Prace przy wznoszeniu kopca miano podjać, mimo kryzysu gospodarczego, który z wolna ustępował dopiero w latach 1933-1934.

W wigilię rozpoczęcia prac budowlanych na Kocich Górkach, tj. 17 września 1932 roku, ks. prałat Wawrzyniec Pucher zaprosił zainteresowanych do kościoła mariackiego na uroczystą Mszę św., podczas której ks. major Bombas w podniosłym kazaniu przedstawił szlachetne cele przyświecające wznoszeniu tak niezwykłego na Śląsku pomnika. Zachęcił do nieustannej modlitwy w intencji rozwijającej się Ojczyzny. Podkreślił, że u podstaw pomyślnego rozwoju Polski stoi społeczeństwo podporządkowane solidarnej pracy, wymagajacej sumienności, wytrwałości i nadziei na przyszłośćc ${ }^{28}$.

${ }^{25}$ Tamże.

${ }^{26}$ Kronika Miejska Piekar - do 1930 r. (Maszynopis przechowywany w Urzędzie Miejskim, s. 86, bez sygn.); PZ $1937 \mathrm{nr} 167$.

${ }^{27}$ Komitet Budowy „Kopca Wyzwolenia” uważal, iż kwota $500 \mathrm{zł}$ za morgę magdeburską stanowi „sprawiedliwą cenę".

${ }^{28}$ C. K. [K. C i s e k ?], Z pięknej uroczystości sypania Kopca, mp., bez sygn., Muzeum Miejskie w Chorzowie. 
Zgodnie z piekarską tradycja, po uroczystościach w kościele w kierunku Kocich Górek wyruszyła wielotysięczna procesja ze sztandarami, feretronami i kwiatami. Na przedzie defilował Korpus Kadetów Nr 2, 3, 4 i 5 ze Lwowa „W sile jednej kompanii”,29, który walczył na Śląsku, z bojowym sztandarem $\mathrm{z}$ lat $1863-1864^{30}$. Wcześniej cały teren został zmierzony przez geodetów, a inż. Eugeniusz Zaczyński z Katowic przygotował projekt kopca. Średnica jego podstawy miała wynosić 68 metrów, wysokość $30 \mathrm{~m}$, a objętość została określona na 25 tys. $\mathrm{m}^{3}$ 31 .

Po przybyciu na miejsce rozpoczęła się druga część uroczystości. Złożyły się na nią przemówienia patriotyczne przedstawicieli władzy lokalnej, wojska i duchowieństwa oraz koncert znanego chóru „Halka” z Piekar Wielkich. Piekarski proboszcz ks. prałat W. Pucher poświęcił miejsce ma którym miał stanąć kopiec $^{32}$. Jednak najważniejszym elementem uroczystości było odczytanie i wmurowanie aktu erekcyjnego pod budowę kopca. Zachowany do dziś uroczysty dokument brzmi następująco:

Działo się to w Wielkich Piekarach dnia 17.LX.1932 r., gdy na Stolicy Apostolskiej zasiadał J. Świątobliwość Papież Pius XI, Prezydentem Rzeczypospolitej byt Profesor Ignacy Mościcki, Pierwszym Marszałkiem Polski Józef Piłsudski, Prymasem Polski J.E. Kardynał Dr August Hlond syn ziemi śląskiej, Wojewodą Śląskim powstaniec Dr Michał Grażyński, Marszałkiem Sejmu Śląskiego Konstanty Wolny, Dowódcą Dywizji Śląskiej Generał Dr Józef Zając, Biskupem Śląskim J. E. Stanisław Adamski, Starostą Powiatu Świętochłowickiego powstaniec Tadeusz Szaliński, Proboszczem Parafii Piekary Wielkie Ks. Prałat Wawrzyniec Pucher, Naczelnikiem Gminy Piekary Wielkie Jan Pudlik, Prezesem Wydziału Związku Powstańców Śląskich powstaniec Jan Lorc, Sekretarzem powstaniec Stanisław Mastalerz, Skarbnikiem powstaniec Franciszek Feige, Prezesem powiatowym Powiatu Świętochłowice powstaniec Józef Trojak i prezesem grupy powstańczej w Piekarach powstaniec Emil Baron, kiedy za wspólną inicjatywą Związku Powstańców Śląskich i Komendy Korpusu Kadetów Nr 1 ze Lwowa, pod wysokim protektoratem Ministra Wyznań Religijnych i Oświecenia Publicznego Rzeczypospolitej Polskiej Janusza Jędrzejewicza, I Wiceministra Spraw Wojskowych Generała Kazimierza Fabrycego, II Wiceministra Spraw Wojskowych Generała Dr Felicjana Sławoja Składkowskiego i Wojewody Śląskiego Dr Michała Grażyńskiego na widomy znak walki i poświęcenia ludu śląskiego o Wolność oraz jako symbol łączności Śląska z Polska, ku uczczeniu pamięci poległych w powstaniach śląskich bohaterów nad brzegami Odry i Góry Św. Anny postanowiono usypać starym zwyczajem polskim kopiec okazały.

Kopiec ten stanie pracą ludu śląskiego bez różnicy stanów. W dniu dzisiejszym do pierwszych prac przystąpił, po poświęceniu gruntów przez Ks. Pra-

${ }^{29} \mathrm{PZ} 1932$, nr 257.

${ }^{30} \mathrm{PZ} 1932$ nr 260. Kadetów tych nazywano popularnie „Ślazakami”. Kompania liczyła 270 osób, które rozlokowano w szkole nr 3 w Piekarach. Opiekowało się nimi lokalne Towarzystwo Polek, pod przewodnictwem p. Siwcowej.

${ }^{31} \mathrm{~W}$ niektórych relacjach prasowych napisano, iż wysokość Kopca wyniesie ok. $20 \mathrm{~m}$.

32 „Piekarskie Wiadomości Parafialne”, (Wielkie Piekary), 1932, nr 38. 
łata Puchera, Komitet Honorowy Budowy Kopca, z prezesem wicewojewodą Dr Tadeuszem Salonim na czele.

Prace fundamentowe wykonują razem z powstańcami kadeci Lwowscy, pod dowództwem ich komendanta pułkownika Kazimierza Florka.

Niech kopiec ten przypomina przyszłym pokoleniom bohaterstwo powstańców śląskich w walce o wolność ziemi śląskiej i jej przynależność do Macierzy. Niech braciom naszym nie wyzwolonym będzie ten kopiec pochodnia nadziei, że i dla nich zawita jutrzenka wolności, niech szczyt kopca będzie widomym znakiem tężyzny narodowej i synonimem hasła: «Nie damy ziemi skąd nasz ród!»" $" 33$.

Odtąd na terenie budowy Kopca czuwał specjalny dozorca. On również zawiadywał Zlota Księga zalożona z okazji budowy KOPCA WYZWOLENLA ŚLASKA w Wielkich Piekarach 1932. Do niej miały wpisywać się zarówno organizacje jak i osoby prywatne przybywające ochotniczo do pracy.

Nazajutrz $z$ wielkim entuzjazmem i zaangażowaniem rozpoczęto prace przygotowawcze $\mathrm{e}^{34}$. W południowej stronie Kopca wytyczono zarys bardzo obszernego placu, przeznaczonego na parady sportowe i wojskowe. Wytyczono także szeroką droge prowadząca wprost do centrum Piekar Wielkich. Podczas tych prac ujawniono, że ,na stokach Kopca od strony południowej będzie ułożony z darniny i kwiecia olbrzymi znak krzyża"35. Wśród bardzo licznej grupy ochotników pracowało także około 300 osób ze Lwowa, przeważnie lwowscy kadeci, którzy wzięli także udział w uroczystości odsłonięcia pomnika poległych powstańców w Bogucicach. Przy pracach obecny był starosta Szaliński i przedstawiciele Zarządu Głównego Związku Powstańców Polskich ${ }^{36}$. Jako Pierwszy „wysypał na środek wznoszonego Kopca ziemię przywiezioną z grobów powstańczych znajdujących się pod Górą Św. Anny na Śląsku Opolskim" prezes Wydziału Związku Powstańców Śląskich starosta Wyględa"37. Liczna młodzież powstańcza z Bielszowic, która do Piekar przyjechała na rowerach, przywiozła w woreczkach ziemię z pól bielszowickich. Pierwszą organizacją żeńską wznoszącą Kopiec było Towarzystwo Młodych Polek z powiatu świętochłowickiego. W maju 1933 roku jego przedstawicielki przywiozły do Piekar ziemię z miejscowego pola walki w czasie powstań śląskich ${ }^{38} .15$ i 16 czerwca 1933 roku członkowie świetlic i wykładów dla bezrobotnych przebywający na wycieczce w Piekarach Wielkich i zwiedzający słynny kościół pielgrzymkowy wybudowa-

${ }^{33}$ Złota Ksiega zatożona z okazji budowy KOPCA WYZWOLENIA ŚLĄSKA w Wielkich Piekarach 1932, Archiwum Stowarzyszenia Miłośników Ziemi Piekarskiej, Piekary Ślaskie, rkp., sygn. I-487; PZ, 1937 nr 167. Zob. też: F. H a w r a n e k, Kopiec Wyzwolenia w Piekarach..., s. 239.

${ }_{34} \mathrm{PZ} 1933$, nr 139.

${ }^{35}$ Tamże.

${ }^{36} \mathrm{P}$ Z 1933, nr 134.

${ }^{37} \mathrm{P}$ Z 1933, nr 139.

${ }^{38}$ Dla nich ks. W. Pucher po dniu znojnej pracy polecił wyjątkowo, w nietypowym czasie, odsłonić obraz Matki Bożej Piekarskiej łaskami słynący. - PZ 1933, nr 157. 
ny $\mathrm{z}$ ofiar biednych ludzi składających na ten cel datki na apel ks. Jana Ficka w latach 1844-1849, również włączylli się w prace przy wznoszeniu Kopca ${ }^{39}$.

Odtąd w prasie polskiej na Górnym Śląsku zaczęły się ukazywać artykuły o charakterze apeli wzywających do wzięcia udziału we wznoszeniu „Kopca Wyzwolenia" w Piekarach Wielkich. Podnoszono w nich, że „fakt ten nie może przejść bez echa ${ }^{, 40}$. „Ofiarną pracą całego społeczeństwa ma powstać dzieło gigantyczne, aby dać świadectwo przyszłym pokoleniom o głębokim umiłowaniu Ojczyzny przez tych, którzy stanęli z bronią w ręku w godzinie potrzeby. Dzieło zapoczątkowane ma się stać synonimem ofiarności tego społeczeństwa polskiego, któremu było dane doczekać się wolnej i niepodległej Ojczyzny. Ofiarna praca i chęć służenia Polsce niechaj sprawi, aby dzieło rosło i potężniało"41.

Na ten apel 11 lipca 1933 roku do Piekar Wielkich przybył 120 osobowy oddział kapeowiaków, czyli członków Kolejowego Przysposobienie Wojskowego rejonu V - Tarnogórskiego. Oddziałowi towarzyszyła wieloosobowa orkiestra dęta, która udała się wraz z nim aż na „wżiesienie górujące nad całą okolicą a które wkrótce znane będzie każdemu dziecku polskiemu"42. Entuzjazm grupy był tak wielki, że do późnych godzin nocnych „,sześć wózków na szynach, kilkanaście taczek poruszało się żywo, zwożąc ziemię i różnej wielkości kamienie na miejsce zaczętego dzieła",43.

14 lipca 1933 roku odbyło się w Piekarach Wielkich, pod przewodnictwem zastępcy naczelnika gminy P. Wróbla, zebranie organizacyjne „naczelników gmin północnej części powiatu świętochłowickiego oraz przedstawicieli organizacji polskich tej części oraz gminy Radzionkowa i Kozłowej Góry"34, mające koordynować zgłoszenia poszczególnych organizacji, które w ramach wycieczki do miejscowości pielgrzymkowej wyrażą chęć wznoszenia Kopca. W trybie natychmiastowym zorganizowano biuro koordynujące przyjmowanie odpowiednich zgłoszeń - którym miał kierować Jan Ludyga, prezes Komitetu Budowy Kopca Wyzwolenia, zatrudniony w urzędzie gminnym w sąsiednim Szarleju - które miało regulować pracami ochotników przyjeżdżających z wycieczkami $^{45} .22$ lipca 1933 roku ukonstytuował się w Piekarach Wielkich jeszcze jeden Komitet, ze starostą powiatu świętochłowickiego T. Szalińskim na czele i ks. W. Pucherem jako jego zastępç, który miał przygotować „godne uczczenie 250. rocznicy przejazdu przez Śląsk króla Jana III Sobieskiego z bo-

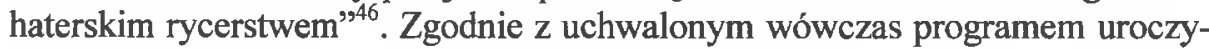
stości, postanowiono „urządzić główne uroczystości w Wielkich Piekarach i połączyć je z poświęceniem Kopca Wyzwolenia,47.

\footnotetext{
${ }^{39} \mathrm{PZ} 1933$, nr 177.

${ }^{40} \mathrm{PZ} 1933$, nr 138.

${ }^{41}$ Tamże.

${ }^{42} \mathrm{PZ}$ 1933, nr 202.

${ }^{43}$ Tamże.

${ }^{44} \mathrm{PZ} 1933, \mathrm{nr} 199$.

${ }^{45}$ Tamże.

${ }^{46} \mathrm{PZ} 1933$, nr 210.

${ }^{47} \mathrm{PZ}$ 1933, nr 201.
} 
Z uroczystościami, które miały odbywać się w dniach 11-13 sierpnia 1933 roku w Piekarach Wielkich zaplanowano także zlot oddziałów żeńskich Stowarzyszenia Młodzieży Polskiej ${ }^{48}$. Tuż po ogłoszeniu tej decyzji chęć przybycia do Wielkich Piekar zgłosiło 4800 druhen: $1370 \mathrm{z}$ Częstochowy, $68 \mathrm{z} \mathrm{Lu}$ blina, 18 z Łucka, 50 ze Lwowa, 340 z Łomży, 460 z Pomorza, 800 z Sandomierza, $341 \mathrm{z}$ Tarnowa, $110 \mathrm{z}$ Wilna. Pozostałe druhny miały przyjechać ze Śląska $^{49}$. Każda z uczestniczek pamiętnego zlotu miała przywieźć grudkę ziemi ze swej miejscowości. W krótkim terminie potwierdzono przyjazd kolejnych druhen z Częstochowy (ich łączna liczba wzrosła do 1500), z Łomży - 300, Pelplina - 470, Płocka - 170, Poznania - 300, Przemyśla - 320, z Tarnowa - dodatkowo 180 druhen i z Siedlec - 100. Akces przyjazdu ciagle zgłaszały kolejne grypy młodzieży żeńskiej zrzeszonej w SMP ${ }^{50}$. Wśród zgłaszających się znalazł się także katolicki „Orel” z Czechosłowacji oraz liczna grupa polskich sympatyków z Niemiec. Prasa polska podkreślała ${ }^{51}$, że „wszyscy przywożą ziemię ze swoich miejscowości, bo na pamiątkę 250 letniej rocznicy Odsieczy Wiednia sypie się w Piekarach [Wielkich] kopiec w hołdzie Sobieskiemu, wielkiemu rycerzowi i dostojnemu Synowi Polski" ${ }^{52}$. Zapowiedziano udział w uroczystościach przedstawicieli Rządu RP, wysokich dostojników Kościoła katolickiego, władz samorządowych i licznych organizacji społecznych ${ }^{53}$. Apelowano, aby ci, którzy sami nie mogą wziąć udziału w uroczystościach, poczuli się do złożenia „odpowiedniego" datku pieniężnego na specjalne konto, którego numer podawała prasa ${ }^{54}$. Do 14 sierpnia 1933 roku przy wznoszeniu Kopca Wyzwolenia przepracowało ponad 100 grup ochotników, nie licząc pojedynczych osób. Proces budowy nadzorował inż. Lissek ze Świętochłowic, odpowiedzialny za sprawy techniczne ${ }^{55}$.

„Dziennik poświęcony sprawom narodowym i społecznym na Kresach Zachodnich" redagowany przez Edwarda Rumuna, a wydawany w Katowi$\mathrm{cach}^{56}, 14$ sierpnia 1933 roku opublikował odezwę Komitetu Obchodu 250-lecia pobytu króla Jana Sobieskiego w Piekarach Wielkich, podpisaną przez Komitet Wykonawczy w osobie starosty dr. T. Szalińskiego i ks. prob. W. Puchera z Piekar Wielkich oraz F. Wróbla, pełniącego obowiązki naczelnika gminy ${ }^{57}$. W odezwie podano szczegółowy program uroczystości, możliwości dojazdu na uro-

${ }^{48} \mathrm{PZ}$ 1933, nr 210; „Polonia” [dalej: P] 1933, nr 3161.

${ }^{49} \mathrm{PZ} 1933$, nr 210.

${ }^{50} \mathrm{P} 1933$, nr 3164.

${ }^{51} \mathrm{P} 1933$, nr 3177, nr 3180, nr 3184, nr 3185, nr 3198.

${ }^{52} \mathrm{PZ} 1933$, nr 221.

${ }^{53} \mathrm{PZ} 1933$, nr 222 i 250.

${ }^{54} \mathrm{PZ}$ 1933, nr 223. Konto czekowe PKO nr 305450 założono w Powiatowej Komunalnej Kasie Oszczędności w Świętochlowicach.

${ }^{55} \mathrm{PZ} 1933$, nr 223.

${ }^{56}$ Chodzi o często cytowaną „Polskę Zachodnią, który to dziennik należy odróżnić od „Polski Zachodniej. Tygodnika poświęconego sprawom narodowym na Kresach Zachodnich”, wydawanego przez Rudolfa Kornke również w Katowicach, ale wyłącznie w latach 1925-1925.

${ }^{57} \mathrm{PZ}$ 1933, nr 223. 
czystość oraz ponowiono apel odwołujący się do sumienia katolickiego i obywatelskiego rodaków ${ }^{58}$.

Po imponujących uroczystościach w Piekarach Wielkich, które $\mathrm{z}$ okazji zlotu katolickiej młodzieży żeńskiej zamieniły się w miasto radości, ale i patriotyzmu i powagi ${ }^{59}$, a w których wzięło udział ponad 6 tys. uczestniczek $\mathrm{z}$ całej Polski ${ }^{60}$, w dniach 11-20 sierpnia 1933 roku zorganizowano ogólnopolski zlot SMP męskiej w Piekarach Wielkich, połączony ze wznoszeniem Kopca Wyzwolenia Śląska $^{61}$. Był on jeszcze bardziej imponujący niż zlot dziewczą ${ }^{62}$. Wzięło w nim udział ok. 12 tys. młodzieży z całej Polski ${ }^{63}$, a uczestników zlotu szacowano na ponad 100 tys. ${ }^{64}$ Przewodniczący Komitetu Zlotowego ks. W. Pucher zamienił kancelarie parafialną w biuro dla sztabu zlotowego, które było czynne w dzień i w nocy. Przyjęto w nim 18 tys. zgłoszeń uczestników spoza Śląska ${ }^{65}$, głównie z Wilna, Pomorza, Wielkopolski. W tych dniach w Piekarach niemal bez przerwy grały orkiestry dęte SMP z Orzegowa, Królewskiej Huty, Knurowa, Ornontowic i Lublińca. Każda delegacja przywiozła z sobą w urnach ziemię, którą złożono na Kopcu Wyzwolenia ${ }^{66}$. Wznoszenie Kopca nie ustało jednak po tych uroczystościach. Już w najbliższą niedzielę, 27 sierpnia 1933 roku Śląski Zarząd Wojewódzki Związku Inwalidów Wojennych zwołał swych członków do Piekar Wielkich na wielką manifestację narodową. Uczestnicy manifestacji złożyli ziemię ze 154 miejscowości Śląska, w których mieszkali bohaterscy obrońcy rubieży Rzeczypospolitej ${ }^{67}$.

24 sierpnia t. r. na Kopiec Wyzwolenia wyruszyła 55. Sztafeta licząca aż 780 uczestników, członków Związu Powstańców Ślasskich powiatu katowickiego z poświęconymi „przez ks. prof. L. Kosyrczyka cegiełkami”, ${ }^{\text {, }}$, zawierają-

${ }^{58} \mathrm{P}$ 1933, nr 3178. Program uroczystości zamieściły także na swoich łamach „Piekarskie Wiadomości Parafialne"[dalej: PWP] 1933, nr 28.

${ }^{59} \mathrm{P} 1933$, nr 3170; PWP 1933, nr 29; nr 33.

${ }^{60} \mathrm{P} 1933, \mathrm{nr} 3177$.

${ }^{61} \mathrm{PZ} 1933, \mathrm{nr} 228$; PWP 1933, nr 31.

${ }^{62} \mathrm{Z}$ Wielkopolski na zlot przyjechało na rowerach aż 1200 druhów. - P 1933, nr 3180.

${ }^{63}$ P 1933, nr 3184; PWP 1933, nr 34. Parafia w Piekarach zdołała na ten okres „zebrac ponad 10 tys. darmowych noclegów masowych".

${ }^{64} \mathrm{P} 1933, \mathrm{nr} 3185$.

${ }^{65} \mathrm{PZ} 1933, \mathrm{nr} 228$.

${ }^{66} \mathrm{PZ} 1933$, nr 230 . Niektóre delegacje posiadały urny z dokumentami, na których zamieszczono nazwiska wszystkich poległych powstańców. W Lipinach np. utworzono specjalny komitet, by wspólnie mogły wyruszyć organizacje wojskowe, półwojskowe ze sztandarami, zbierając do urn ziemię z miejsca, w których Grenzschutz zamordował powstańców w 1919 r. Dołączono do niej ziemię pomordowanych powstańców z Zabrza, „którą krewni poległych przywieźli”. - PZ 1933, nr 227. Powstańcy z Rudy Śląskiej 19 sierpnia 1933 r. wywieźli na Kopiec 56 wozów ziemi; PZ 1933, nr 236.

O wysokim prestiżu narodowo-religijnym tego zlotu świadczyć może pamiątkowa jednodniówka pt. „Ślassk - Sobieskiemu”. Obok artykułów i nowel Zofii Kossak-Szczuckiej, Gustawa Morcinka, Jana Przybyły, Wiktora Polaka, Stanisława Wallisa i Adolfa Ligonia, zawierała ona fotografie upamiętniające budowę Kopca Wyzwolenia i pracę przy nim uczestników Złotów. Sprzedaż tej rzadkiej dziś broszury miała nadto przyspieszyć ukończenie budowy, ponieważ każdy egzemplarz stanowił równocześnie tzw. cegiełkę zasilającą fundusze przedsięwzięcia.

${ }^{67} \mathrm{PZ} 1933, \mathrm{nr} 235$.

${ }^{68} \mathrm{PZ} 1933$, nr 237. 
cymi ziemię z mogił powstańców [śląskich] i dokumentami. Uczestnicy sztafety pracowali cały dzień przy wznoszeniu kopca. Cegiełki zaś jak zapewniał inż. Lissek odpowiedzialny za nadzór techniczny budowy, zostaną, „dopiero zużyte do obramowania kopca ${ }^{69}$. Jeszcze większa grupa ochotników wznoszenia Kopca Wyzwolenia do Wielkich Piekar przybyła 27 sierpnia t.r., z okazji manifestacji Związku Inwalidów Wojennych RP. Zjazd Zarządu 154 ogniw Związku na Śląsku, po części oficjalnej w liczbie 3 tys. członków przystapił do sypania Kopca. „Wzruszająca była scena - napisano w jednym $\mathrm{z}$ artykułów - gdy delegaci z Poznania i Krakowa ( Arkadiusz Zieliński i Zygmunt Sitek) złożyli ziemię z Kopca Kościuszki i Kopca Wolności z Poznania"70.

W październiku 1933 roku generał Feliks Sławoj-Składkowski, szef Administracji Armii, przejął naczelny protektorat nad mającymi się odbyć uroczystościami poświęcenie Kopca Wyzwolenia Śląska ${ }^{71}$. Przed zbliżającą się zimą przy budowie Kopca Wyzwolenia pracowało jeszcze wielu ochotników m. in. członkowie towarzystw z Szarleja, Wielkich Piekar ${ }^{72}$, powstańcy z okręgu rybnickiego ${ }^{73} \mathrm{i}$ inni. Potem roboty ustały ze względu na warunki pogodowe.

Wraz z nastaniem wiosny 1934 roku nie wznowiono prac przy wznoszeniu Kopca Wyzwolenia ${ }^{74}$. Dopiero interwencja starosty świętochłowickiego T. Szalińskiego sprawiła, że w połowie kwietnia prace przy budowie Kopca podjęło 50 bezrobotnych ${ }^{75}$. Okazało się jednak, że dotychczasowa dwuletnia praca „miała w przeważającej części charakter symboliczny”. Międzygminny Komitet Budowy Kopca Wyzwolenia, któremu przewodniczył ławnik J. Ludyga 25 kwietnia 1934 roku zaproponowal, iż należy najpierw zdobyć fundusze, które pozwolą na stałe zatrudnić przy budowie Kopca bezrobotnych. Powzięto zatem niepopularną uchwałę, aby urzędnicy państwowi, samorządowi przedsiębiorcy prywatni z województwa śląskiego dobrowolnie, jednorazowo opodatkowali się w wysokości $1 \%$ uposażenia miesięcznego ${ }^{76}$. Komitet zwrócił się również do wszystkich organizacji narodowych, społecznych i kulturalnych województwa śląskiego o moralne i finansowe poparcie akcji budowy Kopca w Wielkich Pie-

\footnotetext{
${ }^{69}$ Tamże.

${ }^{70} \mathrm{PZ} 1933$, nr 239.

${ }^{71} \mathrm{PZ} 1937, \mathrm{nr} 167$.

${ }^{72} \mathrm{PZ} 1933, \mathrm{nr} 274$.

${ }^{73} \mathrm{PZ} 1933$, nr 309.
}

${ }^{74} \mathrm{~W}$ społeczeństwie brakowało entuzjazmu $\mathrm{z}$ poprzednich lat. Wynikało to m.in. z uchwalonych w $1933 \mathrm{r}$. ustaw antyrobotniczych o czasie pracy w przemyśle, o urlopach i ubezpieczeniach społecznych. W wielu miastach, m.in. w Częstochowie i Zawierciu, wybuchły strajki przeciwko uchwalonym ustawom antyrobotniczym. Następowała radykalizacja nastrojów społecznych. Wzrastała liczba bezrobotnych - w marcu 1934 r. zarejestrowano już prawie 400 tys.

${ }^{75} \mathrm{PZ} 1934$, nr 73.

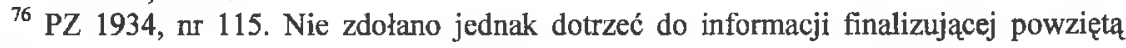
uchwałę. 
karach. Upłynęło jednak ponad trzy miesiące, zanim roboty przy wznoszeniu Kopca nabrały tempa. Dopiero w trzecim kwartale 1934 roku, ,nie było dnia, by nie przybyła chociaż jedna wycieczka ze Ślaska, pracująca ofiarnie i cały dzień przy budowie kopca" ${ }^{977}$. W październiku t.r. honor na budowie Kopca ratowali głównie peowiacy ze Śląska, którzy przybywali nieraz w grupach liczących po 400 osób $^{78}$. Pod koniec roku 1934 stan budowy przedstawiał się następująco: zdołano usypać $17.240 \mathrm{~m}^{3}$ kamieni i ziemi. Do zakończenia prac budowlanych należało zatem dodać około $10.760 \mathrm{~m}^{3}$ potrzebnego surowca; udział w pracach wzięło dotąd 9.565 osób, głównie z należących do organizacji wojskowych, półwojskowych oraz kulturalno-oświatowych województwa śląskiego ${ }^{79}$.

W komunikacie prasowym $\mathrm{z}$ dnia 21 lutego 1935 roku podano, że „w roku bieżącym i następnym prace przy sypaniu Kopca wymagać będą specjalnych urządzeń technicznych, co pociągnie za sobą zwiększone wydatki»80. Do optymistycznych wniosków należy zaliczyć przytoczone $\mathrm{w}$ prasie stwierdzenie: „obecnie Kopiec ma już 25 metrów wysokości i widoczny jest w szerokim promieniu okręgu przemysłowego oraz poza granicami państwa"81.

W drugiej połowie kwietnia 1935 roku głównie dzięki zabiegom starosty T. Szalińskiego, na budowie Kopca zainstalowano prymitywne urządzenia wyciagowe, dzięki którym prace posuwały się szybciej. Ofiarnie pracowali bezrobotni zatrudnieni przy wyciąganiu metalowych wozów kopalnianych na szczyt $\mathrm{Kopca}^{82}$. Choć wielu uczestników prac łączyło zajęcie przy budowie $\mathrm{z}$ wycieczkami w okoliczne lasy, Międzygminny Komitet Budowy Kopca Wyzwolenia optymistycznie sądził, że prace zdoła się ukończyć w 1936 roku $^{83}$.

W pierwszej połowie sierpnia 1935 roku „starszyzna powstańcza” zwołała jednak specjalne zebranie w Wielkich Piekarach. Powodem był niepokój związany z nikłym postępem prac przy wznoszeniu Kopca Wyzwolenia. W czasie zebrania prowadzonego przez mecenasa $\mathrm{J}$. Witczaka zebrani członkowie Wydziału Związku Powstańców Śląskich usłyszeli, iż dotychczas zdołano przemieścić ok. 20 tys. $\mathrm{m}^{3}$ ziemi. W czasie gorącej dyskusji stwierdzono, iż „bardzo duża ilość wycieczek przychodzi na Kopiec Wyzwolenia raczej w celach rozrywkowych" i „symbolicznie bawi się [jego] sypaniem"84. Postanowiono, iż odtąd organizacje przybywające na Kocie Górki muszą zadbać o to, „ażeby każdy przybywający na kopiec nasypał przynajmniej trzy wózki ziemi i zawiózł je na przeznaczone miejsce. Tylko wówczas będzie można mówić o spełnionym obowiązku." W tym celu należy maksymalnie wykorzystać pozostałą „część lata i jesień do urządzenia wycieczek na Kopiec Wyzwolenia i do Piekar,

${ }^{77} \mathrm{PZ} 1934, \mathrm{nr} 265$.

${ }^{78} \mathrm{PZ} 1934, \mathrm{nr} 301$.

${ }^{79} \mathrm{PZ} 1935, \mathrm{nr} 54, \mathrm{nr} 181, \mathrm{nr} 201$

${ }^{80}$ Tamże.

${ }^{81}$ Tamże.

${ }^{82} \mathrm{PZ} 1935$, nr 111. W tym czasie bezrobotni w Polsce stanowili problem nie polityczny, a spoleczny.

${ }^{83} \mathrm{PZ} 1935, \mathrm{nr} 191$.

${ }^{84} \mathrm{PZ} 1935, \mathrm{nr} 224$. 
i zabrać się tam do rzetelnej i wydajnej pracy" ${ }^{85}$. Jako pierwszy do tych ustaleń zastosował się krakowski oddział Związku Powstańców Polskich, który pobrał ziemię ze Wzgórza Wawelskiego i z Kopca Piłsudskiego na Sowińcu, po czym wyruszył do Piekar ${ }^{86}$, aby „,nasypać 3 wózki ziemi”. Ofiarnie przy wznoszeniu Kopca Wyzwolenia pracował Zwiazek Powstańców Śląskich z Wielkich Hajduk, który „w liczbie 119 członków i 34 źon z dziećmi 24 sierpnia 1935 roku załadował aż 261 wózków ziemi”, ${ }^{87}$.

Z początkiem listopada 1935 roku - mimo wcześniejszych pomiarów otwarta pozostała kwestia aktualnej wysokości Kopca Wyzwolenia. Powtórne pomiary wykazały, iż dotąd zdołano usypać wysokość $17 \mathrm{~m}$, a nie 20, jak planowano w roku poprzedzającym. Komunikat prasowy zapowiadał, że docelowa wysokość Kopca Wyzwolenia nie będzie wynosić $30 \mathrm{~m}$, a tylko $25^{88}$. Informowano również, że „budowa Kopca została zrealizowana z okazji 15 lecia odzyskania Niepodległości Gómego Śląska", co stanowiło istotną zmianę pierwotnych ustaleń. Po kolejnej zimie okazało się jednak, że wysokość usypanego kopca wynosi zaledwie $12 \mathrm{~m}$, co równa się $29536,10 \mathrm{~m}^{3}$, względnie $88668 \mathrm{ob}$ jętości wózków kopalnianych, którymi wciągano na szczyt Kopca ziemię ${ }^{89}$. Po raz pierwszy podano do publicznej wiadomości, iż wiele organizacji wojskowych i parawojskowych urządziło kwestę na budowę Kopca Wyzwolenia, a każde ogniwo zebrało od 50 do $60 \mathrm{zł}$. Bardziej kontrowersyjna nie tylko dla społeczeństwa Górnego Śląska okazała się informacja, dotycząca „wyciagu technicznego na Górę Wyzwolenia"90. Jej autor nie tylko samowolnie zmienił nazwę budowanego kopca, ale także podał nieprawdziwą informację, jakoby dopiero 15 maja 1936 roku został uruchomiony wyciag szynowy, po którym posuwały się wózki górnicze $\mathrm{z}$ kamieniami i ziemią ${ }^{91}$. Wcześniejsze doniesienia prasy regionalnej, pochodzące z 1933 roku informowały, że taki wyciag, chociaż prymitywny, jest nie tylko zainstalowany na wznoszonym Kopcu Wyzwolenia, ale ponadto spełnia swoją funkcję. Na temat Kopca Wyzwolenia w Wielkich Piekarach zaczął zatem funkcjonować szum informacyjny, który de facto dezinformował opinię publiczną.

Ponieważ termin oddania obiektu-symbolu na Kocich Górkach był zagrożony, organizatorzy uroczystości odsłonięcia tablicy ku czci 94. poległych peowiaków i powstańców z powiatu zabrskiego, odbywającej się w Piekarach w dniu 17 maja 1936 roku na terenie sanktuarium maryjnego, zwrócili się do uczestników o bardziej aktywny udział we wznoszeniu Kopca ${ }^{92}$. Można jednak przypuszczać, że także ich 2-4 godzinna praca miała raczej charakter rekreacyj-

\footnotetext{
${ }^{85}$ Tamże.

${ }^{86} \mathrm{PZ} 1935, \mathrm{nr} 232$.

${ }^{87} \mathrm{PZ} 1935$, nr 235.

${ }^{88} \mathrm{PZ} 1935, \mathrm{nr} 309$.

${ }^{89} \mathrm{PZ} 1936, \mathrm{nr} 56$.

${ }^{90} \mathrm{PZ} 1936, \mathrm{nr} 134$.

91 Tamże.

${ }^{92} \mathrm{PZ} 1936$, nr 135.
} 
ny ${ }^{93}$. Zdarzały się jednak sytuacje odmienne, o czym wspomina Złota Księga: „W dniu 20 maja 1936 roku Stowarzyszenie Ochotniczych Straży Pożarnych z Chropaczowa brało udział w sypaniu Kopca Wyzwolenia w sile 4 oficerów i 22 członków czynnych i 1 członek zarządu" "94. Prace tej grupy przerwał jednak długotrwały deszcz. Identyczna sytuacja miała miejsce kilka dni później, gdy z Katowic do Wielkich Piekar przyjechało 82 członków Stowarzyszenia Tramwajarzy Górnego Śląska. Zdołali oni załadować zaledwie 12 wagoników piaskiem i kamieniami; ale pracę musieli przerwać z powodu ulewy. Żal z tego powodu wyrazili na kartach cytowanej Złotej Ksiegi. „W tym samym miesiącu roboty ruszają większą mocą. Wśród pracujących zjawiają się Powstańcy Wielkopolscy, Orlęta Lwowa, Weterani 1863, przywożąc ziemię z pobojowisk i grobów poległych bohaterów" 95 .

Większy ruch przy budowie Kopca i bardziej zaangażowana praca panowały w dniach 21-28 czerwca 1936 roku. Związek Powstańców Śląskich z Żyglina, Kalet, powiatu strzeleckiego, Lasowic, Chorzowa, a także Zwiazek Weteranów, Właścicieli Nieruchomości Piekary Śląskie, Związek Rezerwistów powiatu świętochłowickiego i piekarskiego oraz Zwiazek Zachodni z Katowic Dębu zaangażowały się w całodzienną pracę $e^{96}$; swój udział z budowie Kopca zgodnie $\mathrm{z}$ ustalonym regulaminem budowy, zgłosiły wcześniej, ponieważ obecnie „na kopcu moga jednocześnie pracować tylko ograniczone grypy ludzi”,97. Inicjowany przez zarządzenia organizacyjne ruch wyjazdu do Piekar i udział w budowie Kopca nie ustawały. Do 5 lipca 1936 roku kilka organizacji powstańczych i rezerwistów z centrum przemysłowego Górnego Ślaska wywiozło na szczyt wznoszonego Kopca 490 wózków górniczych ziemi, około $193 \mathrm{~m}^{398}$. W kolejnym tygodniu inne organizacje miały gorsze wyniki: 220 wózków, względnie $73 \mathrm{~m}^{3}$ ziemi $^{99}$. Odtąd „Polska Zachodnia” zaczęła regularnie podawać nazwy organizacji biorących udział we wznoszeniu Kopca i osiagane przez nie wyniki $^{100}$. Okazało się to skutecznym dopingiem. Warto zaznaczyć, że w ramach akcji prasowej z inicjatywy urzędników i robotników kopalni „Maks” w Michałkowicach [Siemianowicach Śl.] 24 sierpnia 1936 roku około 300 osób załogi, pod kierownictwem inż. J. Żyły, wyruszyło rowerami i autobusami do

${ }^{93} \mathrm{~W}$ innych dniach na budowie Kopca panował ruch. Np. 7 czerwca 1936 r. grupa członków Towarzystwa Polek Katolickich z Dębu, w liczbie 110 osób, nie tylko załadowała 50 wagonikow ziemia, ale nadto wywiozła je pod szczyt kopca siłą własnych mięśni, przerywając pracę wspólną modlitwa. Trzeba jednak stwierdzić, że zdarzały się dnie lub nawet tygodnie, gdy na budowie Kopca brakowalo rąk do pracy. W 1934 r., gdy Wielkie Piekary zostały połączone z Szarlejem, naczelnik gminy znowu musiał energicznie zabiegać o przybywanie delegacji, szczególnie kombatantów i młodzieży, by pomogły w budowie pomnika na Kocich Górkach. Jego zdaniem prace posuwały się tam zbyt wolno i groziły zastojem. Zdarzały się również sytuacje odmienne, o czym wspomina Ztota Ksiega.

${ }^{94}$ Ztota ksiega założona $z$ okazji budowy..., s. 10.

${ }^{95} \mathrm{PZ} 1937, \mathrm{nr} 167$.

${ }^{96} \mathrm{PZ}$ 1936, nr 180.

${ }^{97} \mathrm{PZ} 1936, \mathrm{nr} 150$.

${ }^{98} \mathrm{PZ} \mathrm{1936, \textrm {nr } 1 8 8 .}$

${ }^{99} \mathrm{PZ} 1936, \mathrm{nr} 193$.

${ }^{100}$ Np. PZ 1936, nr 201, nr 212, nr 221, nr 229, nr 243, nr 262, 1937 nr 98. 
Piekar, aby wziąc udział we wznoszeniu kopca. Inicjatywa załogi kopalni była „pierwszą tego rodzaju od początku budowy Kopca", co podkreślała prasa ${ }^{101}$. Nie znalazła ona naśladowców.

W 1937 roku [Międzygminny?] Komitet Budowy Kopca przystapił do prac dopiero $15 \mathrm{kwietnia}^{102}$. Nastapiło to po rozmowach z delegacjami Kolejowego Przysposobienia Wojskowego dyrekcji kolejowych Warszawy, Białegostoku, Wilna, Krakowa, Lodzi i Lwowa, które gościł w Piekarach aktywny działacz społeczno-oświatowy, a zarazem kościelny Karol Cisek ${ }^{103}$. W tym miesiącu także ostatecznie ustalono, że poświęcenie Kopca Wyzwolenia Śląska odbędzie się nie 20 sierpnia ( 250 rocznica przemarszu przez Piekary wojsk Jana III Sobieskiego wyruszającego na Wiedeń w 1683 roku już minęła), ale 20 czerwca 1937 roku, tj. w 15 rocznicę wkroczenia Wojsk Polskich na Śląsk ${ }^{104}$. Jednocześnie wyrażano obawy, czy termin ten zostanie dotrzymany, ponieważ „ukończenie wielkiego pomnika ludu śląskiego wymaga jednak jeszcze wiele pracy". W związku z tym 20 kwietnia t.r. na miejscu budowy przeprowadzono inspekcję, oceniającą stan prac końcowych. W inspekcji uczestniczyli: starosta powiatu świętochłowickiego T. Szaliński, dyrektor Funduszu pracy dr Obierek, inżynier Wydziału Powiatowego Liszak i naczelnik gminy Piekary, poseł Płonka. W rezultacie inspekcji postanowiono w trybie natychmiastowym zatrudnić 400 bezrobotnych do prac ,przy ukończeniu drogi łączącej Kopiec z Piekarami, a następnie przy wyrównaniu i uporządkowaniu terenu koło Kopca oraz przy sypaniu samego Kopca, do którego ukończenia brakuje jeszcze ok. półtora metra"105. $\mathrm{Na}$ innym spotkaniu organizacyjnym uznano, że „hasłem wszystkich organizacji i towarzystw polskich na Śląsku powinno być w tej chwili «Jeszcze raz do Piekar na Kopiec, przyłożyć jeszcze jedną cegiełkę do tego wielkiego dzieła»"106.

7 maja 1937 roku w sali p. Komora przy ul. Mariackiej nr 34 w Piekarach odbyło się zebranie organizacyjne Gminnego Komitetu Uroczystości Poświęcenia Kopca ${ }^{107}$, a 23 maja t.r., tj. w niedzielę, posiedzenie Komisji Prasowo-Propagandowej Komitetu $^{108}$. Odtąd sprawy organizacyjne związane $\mathrm{z}$ oddaniem do użytku publicznego Kopca Wyzwolenia zaczęły nabierać zawrotnego tempa. Prasa codziennie zamieszczała wiele informacji na temat zakończenia budowy Kopca Wyzwolenia. 13 maja ogłoszono, że „Sypanie Kopca Wyzwolenia dobiega końca. Wznoszony obiekt okładano darnią regulowane i umocowywane

${ }^{101} \mathrm{PZ} 1936, \mathrm{nr} 237$.

102 14.04.1937 r., z inicjatywy Zarządu Głównego Związku Powstańców Śląskich, odbyło się w Katowicach posiedzenie komitetu organizacyjnego, na którym wybrano prezydium honorowe dla uczczenia 15 . rocznicy wkroczenia na Górny Śląsk Wojska Polskiego. W jego skład weszli: wojewoda śląski dr M. Graźyński, biskup śląski S. Adamski, płk N. Sadowski, marszałek sejmu śląskiego K. Grzesik i senator R. Kornke. - „Gazeta Tarnogórska” z dn. 17 kwietnia $1937 \mathrm{r}$.

${ }^{103}$ PWP 1937, nr 16.

${ }^{104}$ PZ 1937, nr 103; nr 107; „Gazeta Tarnogórska”. Czasopismo na miasto i powiat Tarnowskie Góry 1937, nr 356.

${ }^{105} \mathrm{PZ} 1937, \mathrm{nr} 109$.

${ }^{106} \mathrm{PZ} 1937, \mathrm{nr} 130$

${ }^{107} \mathrm{PZ} 1937, \mathrm{nr} 128$.

${ }^{108} \mathrm{PZ} 1937$, nr 139. 
są drogi do Kopca, prowadzące od strony południowej i północnej, niwelowany jest plac pod Kopcem itd." 109 maja t.r. w czasie wielkich uroczystości harcerstwa śląskiego w Piekarach na Kopcu złożono kamień pamiątkowy ${ }^{110}$, zasadzono 22 lipy symbolizujące 22 hufce harcerskie na Śląsku ${ }^{111}$. W uroczystości rozpoczętej w sobotę 5 czerwca 1937 roku $^{112}$ wzięło udział około 7 tys. harcerzy, wśród których znalazły się delegacje z Choragwi Krakowskiej i Zagłębiowskiej $^{113}$. Na mszy św. w kościele pielgrzymkowym, celebrowanej przez bpa S. Adamskiego $\mathrm{z}$ Katowic $\mathrm{w}$ asyście kilku księży, byli obecni m.in. prezes ZHP wojewoda dr M. Grażyński, władze wojewódzkie, powiatowe, samorządowe i związkowe ${ }^{i 14}$. Podkreślano, że „30 maja - to dzień głębokiego przeżycia młodzieży harcerskiej i zadokumentowanie, że harcerstwo realizuje czynnie i pogłębia swoje ideały, w myśl naczelnych dewiz skautowych «służę Bogu i Ojczyźnie»" ${ }^{\prime 15}$. W ten sposób Kopiec jeszcze przed oficjalną uroczystością poświęcenia zaczął pełnić funkcje publiczna, "wchodząc" tym samym w historię miejscowości i regionu.

\section{IV}

Od 1 czerwca 1937 roku wszystkie sekcje Komitetu Wykonawczego uroczystości 15 rocznicy wkroczenia Wojsk Polskich na Górny Śląsk organizowały posiedzenia sprawozdawcze ${ }^{116}$. Przygotowywano się na przyjęcie w Piekarach ok. 30 tys. gości.

Dnia 4 czerwca t.r. Prezydium Komitetu Wykonawczego w osobach: R. Kornke - senator RP., Prezes Zarządu Głównego Związku Powstańców Polskich inspektor J. Żóttaszek, Komendant Główny Policji Województwa Śląskiego, starosta J. Wyględa, naczelnik E. Tomanek, Komendant Główny Związku Powstańców Śląskich M. Kopiec, R. Szefer, starosta T. Szaliński oraz poseł B. Płonka, wystosowało Odezwe przed uroczystościq 15-lecia wkroczenia Wojsk Polskich na Ziemię Ślqska. W kontekście aktywnej propagandy antypolskiej

${ }^{109} \mathrm{PZ} 1937, \mathrm{nr} 130$.

${ }^{110}$ Napis na kamieniu brzmial: „W 15 lecie oswobodzenia Śląska w holdzie Bohaterom Powstań - 30. V. 1937 - harcerze śląscy."

${ }^{111} \mathrm{PZ} 1937, \mathrm{nr} 143 ; \mathrm{GN} 1937$, nr 17.

112 PWP 1937, nr 23; nr 24.

${ }^{113}$ PZ 1937, nr 147.

${ }^{114}$ Komendantem Zlotu był Leon Fus. - PWP 1937, nr 24.

${ }^{115} \mathrm{PZ} \mathrm{1937,} \mathrm{nr} \mathrm{143.} \mathrm{Imponująca} \mathrm{uroczystość} \mathrm{u} \mathrm{podnóża} \mathrm{Kopca} \mathrm{Wyzwolenia} \mathrm{Ślasska} \mathrm{za-}$ kończyła się defiladą wszystkich oddziałów harcerskich przybyłych do Piekar. Oglądało ją wiele tysięcy mieszkańców miasta i pielgrzymi przybyli specjalnie w tym dniu do świątyni z obrazem Matki Bożej cudami słynącym. Zebrani zachwycali się sprawnością harcerzy - co podkreślano w polskiej prasie. Wojewoda śląski M. Grażyński zlecił reżyserowi Eugeniuszowi Sikorskiemu sporządzenie filmu dokumentalnego z przebiegu tej manifestacji, który po dzień dzisiejszy stanowi świadectwo tamtych chwil.

${ }^{116} \mathrm{PZ}$ 1937, nr 148; PWP 1937, nr 25. 
prowadzonej przez hitlerowców, szczególnie na Ślassku Opolskim ${ }^{117}$, penetracji hitlerowskiej na Górnym Śląsku i prowokacji hitlerowskich nawet w Piekarach $^{118}$ odezwa miała charakter ideowo - doktrynalny; podkreślała - używając patetycznych określeń podstawowe wartości religijno - narodowe, wówczas oczywiste i niepodważalne. Składały się one na tożsamość polskiego społeczeństwa na Górnym Ślasku, kształtowaną w życiu jednostek i społeczeństwa polskiego na Górnym Śląsku od połowy XIX wieku przez grupe ideowych przewodników, której wzorzec przywódczy zmieniał się w zależności od sytuacji historycznych ${ }^{119}$. A oto dokument ten w pełnym brzmieniu:

\section{RODACY!}

Dnia 20 czerwca br. Śląsk obchodzi pamiętną rocznicę skruszenia pęt niewoli i zrzucenia obcego jarzma, rocznicę wkroczenia Wojsk Polskich na ziemie śląska - w tej dziejowej chwili, kiedy po wielokrotnym znojnym trudzie krwawych walk orężnych z ciemięzcą śląski Powstaniec złożył oręż i broń u stóp polskiego Żołnierza.

\section{ŚLAZACY!}

Wielki ów dzień cały Śląsk święcić będzie w Piekarach Śląskich, w najdroższym Ślązakowi miejscu, gdzie król Jan III Sobieski, spieszacc z odsieczą Wiednia, modlił się do Przenajświętszej Panny Piekarskiej o zwycięstwo orezża polskiego nad nawałą islamu - gdzie z zgasłych oczu śląskiego Wernyhory spłynęły łzy szczęścia i radości, gdy chciwym uchem złowił tętent koni polskich szwadronów ułańskich.

W tym świętym i drogim sercu Ślązaka miejscu twarde ręce Powstańca i całej społeczności śląskiej usypały Kopiec Wyzwolenia, jako niezniszczalne świadectwo swego rycerskiego ducha, jak i swej zdecydowanej woli wytrwania w pracy pokojowej koło umocnienia pochodu polskości na piastowskiej ziemi śląskiej.

Poświęcenie Kopca Wyzwolenia będzie ponownym ślubem ludu śląskiego, że nie ustanie w znojnym i ofiarnym trudzie budowania epokowych podwalin mocy i potęgi Rzeczypospolitej, że przeciwnie w pracy tej zwiększy wolę i wysilek.

Zarazem zaś piekarskie święto unaoczni całej Polsce, że lud polski na Śląsku obowiązki swoje wobec państwa stawia przed prawa i przywileje, że jego zwartość ideowa jest najbardziej twórczym elementem naszego życia narodowego i państwowego, i że twardy w swej codziennej pracy swojej lud śląski jest i pozostanie tak samo twardy i nieustępliwy w rzetelnej pracy dla dobra Narodu i Państwa.

Cała Polska wtedy zrozumie, że żywiołowy pęd i niezmienna wola Ślązaka w odniesieniu do dzieła ugruntowania mocy i potęgi Państwa są zara-

${ }^{117} \mathrm{PZ}$ 1937, nr 304 z obszernym artykułem na temat działalności wrocławskiej kurii biskupiej, która zamierzała uniemożliwié pielgrzymki religijne do Polski, głównie na Jasną Górę i do Krakowa.

${ }^{118}$ Np. PZ 1937, nr 160.

119 A. K w i a t e k, Przywódca i przywództwo narodowe na Górnym Ślasku w polskiej tradycji (1848-1914), Opole 1991, passim. 
zem niezaprzeczalnym tytułem jego pełnosprawnego udziału w twórczej pracy całego Narodu. Całe też społeczeństwo polskie własciwie oceni i uzna, jak olbrzymia pozycją dodatnią jest w pracy tej całokształcie wysiłek i trud, jaki lud ślasski dokonywa w ramach i granicach swego samorządu, udostępniającego Polsce wszystkie wartości, jakim szczycą się dusza i umysłowość ludu polskiego na Śląsku.

\section{RODACY!}

W święcie piekarskim weźmie udział cały Śląsk polski, dokumentując ponownie niezachwianą wiare swoją w zbawienność prastarego hasła polskiego: BÓG I OJCZYZNA! ${ }^{120}$

W ślad za nim i przyspieszeniem prac nad wznoszeniem Kopca Wyzwolenia nasilono kampanię prasowa która miała na celu zmobilizować społeczeństwo polskie na Górnym Śląsku do głębszego zaangażowania patriotycznego w skali masowej. Ich wyraz stanowią takie artykuły, jak np. Tam, gdzie stoi pomnik wzniesiony rękami ludu śląskiego. Trochę historii Piekar Ślaskich ${ }^{121}$, Spetnity się sny pokoleń... ${ }^{122}$, Nieznane pomniki polskości Piekar Ślaskich, Z piekarskich legend $i$ klechd, Żotnierskie pozdrowienie P. Premiera do Powstańców ślqskich i społeczeństwa ślqskiego! lub Ze szczytu będziemy spogladać na ziemię Opolska... Jak powstat Kopiec Wyzwolenia? ${ }^{123}$, i wiele innych.

Jeszcze przed uroczystością poświecenia Kopca, 5 i 6 czerwca 1937 roku . w Piekarach urządzono zlot druhów zrzeszonych w Katolickim Stowarzyszeniu Młodzieży Męskiej i Towarzystwie Alojzjanów, „by uczcić setną rocznicę wielkiego poety i kapłana patrioty śląskiego ks. Norberta Bonczyka oraz upamiętnić 15 rocznicę powrotu Śląska do Macierzy"124. Drugim punktem programu było „sypanie Kopca Wyzwolenia"125, kolejnym - ślubowanie, by „,wzorem ojców i praojców... wychować samych siebie na prawdziwych członków Kościoła, byśmy mogli z pożytkiem spełniać nasze zadania apostolskie... strzec jako najdroższego skarbu wiary świętej. Nią promieniować tak, aby zasady Syna Twego, jako siły ożywcze, płynęły przez wszystkie dziedziny życia i kultury."126

Z zachowanej Zlotej Księgi zalożonej z okazji budowy KOPCA WYZWOLENLA ŚLASSKA w Wielkich Piekarach 1932 rok wynika, że w przedsięwzięciu brały udział pojedyncze osoby, rodziny, a przede wszystkim organizacje społeczno-narodowe ${ }^{127}$, rzadziej religijne. Najstarszym ,budowniczym" był uczestnik powstania styczniowego z 1863 roku P. Tarnowski, który do Piekar dojechał o własnych siłach. Po zwiedzeniu kościoła pielgrzymkowego w towarzystwie znajomych, udał się na Kocie Górki i ładował ziemię oraz kamienie do kopalnianego wózka. Natomiast do najmłodszych ochotników pomagających przy

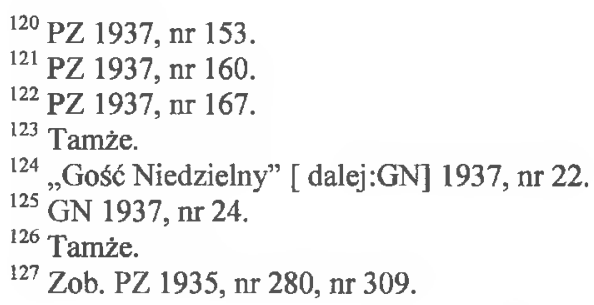


wznoszeniu pomnika należały dzieci z klas czwartych, które w ramach wycieczki krajoznawczej, względnie zajęć lekcyjnych, wraz ze swymi nauczycielkami stosunkowo często przybywały na plac budowy.

Nie sposób wymienić wszystkich organizacji i stowarzyszeń przybywających do Piekar w swych mundurach (często ze sztandarami), by kontynuować budowę Kopca. Najczęściej były to: Ogólny Zwiazek Podoficerów Rezerwy, Koło Przyjaciół Harcerzy, Związek Prawników i Ekonomistów PKP, Zespół Przysposobienia Wojskowego Oddział Drogowy, Zwiazzek Obrony Kresów Zachodnich, Związek Poszkodowanych Uchodźców Śląskich, Policjanci Województwa Śląskiego, Kulturalno-Oświatowa Organizacja Kobiet, Peowiacy, Młode Polki, Bagażowi Dworca Katowickiego, Koła Krajoznawcze, liczne gniazda Towarzystwa Gimnastycznego „Sokół”, Związki Strzeleckie, Kółka Rolnicze, Kongregacje Mariańskie, Ochotnicze Kolumny Sanitarne Czerwonego Krzyża, Zarządy Gminne, Związki Posiedzicieli Domów, Pracownicy Biur Warsztatów Wagonowych, Związki Młodzieży Ludowej, Państwowe Seminaria Nauczycielskie, Związki Pracowników Umysłowych ZZP, organizacje emerytów, przedstawiciele rad parafialnych, kołek zainteresowań i sportowcy ${ }^{128}$.

W budowę Kopca szczególnie zaangażowana była rodzina Walerianów, która na plac budowy przybywała w liczbie 40 osób. Pracami jej nie kierował inż. Lissak [Liszak?], ale energiczny dziadek Ludwik. Jego ambicją było załadowanie aż kilkunastu wagoników gómiczych ziemi, co potrafił wyegzekwować ${ }^{129}$.

W pracach nad wzniesieniem Kopca Wyzwolenia uczestniczyli również znani pisarze, jak: Gustaw Morcinek, Pola Gojawiczyńska i Kazimierz Gołba. Z polityków udział wzięli Wojciech Korfanty i Konstanty Wolny.

Bardzo wcześnie ukształtował się zwyczaj przybywania na miejsce Budowy Kopca Wyzwolenia licznych wycieczek, które przywoziły z sobą grudki ziemi pobranej z miejsc uświęconych historią Polski. 8 lipca 1933 roku ,30-osobowa grupa Związku Powstańców z Rudy Śląskiej przybyła do pracy, przynosząc $\mathrm{z}$ sobą ziemię $\mathrm{z}$ miejsca, na którym zginął $\mathrm{z}$ rąk zbirów niemieckich $\mathrm{p}$. Wincenty Janas, nauczyciel i męczennik sprawy polskiej w Rudzie"130. 9 maja 1936 roku, w ramach obchodów zwiazanych z uroczystością rocznicy uchwalenia Konstytucji 3 Maja, do Piekar przybyło szczególnie dużo delegacji, przywożących z sobą ziemię z następujących miejscowości i pobojowisk: „Z Helu obok mola, z Lidy - z zamku księcia Giedymina, z Grodna z zamku króla Stefana Batorego, z Ostrej Bramy w Wilnie, z Kamiennej Góry w Gdyni, z Bydgoszczy $-\mathrm{z}$ Grobu Powstańców, z przykościelnego cmentarza parafii św. Jerzego w Gnieźnie, z Torunia - z Pomnika Marszałka Józefa Piłsudskiego, z Jarosławia - z grobu pułkownika włoskiego Nulla walczącego w powstaniu 1863 roku, z Olzy - miejscowości 3 państw, z Mysłowic $-\mathrm{z}$ byłego trójkąta trzech zabor-

${ }^{128}$ Złota Księga założona z okazji budowy..., passim.

${ }^{129}$ Tamże.

130 Przed męczeńską śmiercią znakomitego nauczyciela chciał uratować Niemiec Schwartzer, ale został on zadenucnjowany przez ,kobietę idącą do kościoła [!]”. - M. T o b i a s z, Nauczyciel Wincenty Janas, Katowice 1938, s. 56 i ns. 
ców, Żor Jankowskich z pola walki z husytami, z Mirowa - Iskrzyczyna z miejsca walki z Czechami, z Kalisza, Skrzeczowa i Stonawy - z miejsc káźni dokonanej przez Niemców, z Cierlicka - miejsca wypadku samolotowego śp. Żwirki i Wigury, z Jabłonkowa -z grobu legionistów polskich, Jędrzejowa spod domu Marszałka Józefa Piłsudskiego ${ }^{131}$, $\mathrm{z}$ mogiły Juliusza Ligonia w Chorzowie $^{132}$.

Do tej akcji włączyli się także harcerze i harcerki, szczególnie w 1937 ro$\mathrm{ku}$. Rok ten obfitował bowiem w wiele wydarzeń patriotyczno-religijnych, mających miejsce właśnie pod Kopcem Wyzwolenia, którego budowa dobiegała końca. W maju tego roku druhny przywiozly ziemię - jak odnotowano w Ztotej Księdze - ,ze wszystkich miejsc słynnych z bitew Polski”, a więc z Żółkwi, Łuków Wielkich, Trembowli, Pskowa, Nowogródka, Królewca, Wilna, Warszawy, Racławic, Psiego Pola, Legnicy, Stoczka, Cedyni, Niemczy, Grunwaldu, Głogowa, Lwowa, Krakowa i Tarnowa. Delegacja druhen z Gdyni przywiozła wtedy z soba nawet piasek i wodę z Bałtyku. Technik budowlany Jan Bodera, zatrudniony przy budowie Kopca Wyzwolenia gromadził także odpowiednią dokumentację, w której zachowało się wiele cennych dzisiaj informacji dotyczących wspomnianej uroczystości. Ponadto, przy innej okazji, Związek Strzelecki z Częstochowy złożył u stóp Kopca Wyzwolenia ziemię z pomnika ks. Kordeckiego - słynnego obrońcy Jasnej Góry, Stowarzyszenie Młodzieży Polskiej z Sokolnik koło Lwowa „dało ziemię z grobów obrońców i ofiar pomordowanych za Ojczyznę, przez Ukraińców", Ochotnicza Kolumna Sanitarna i Zwiazzek Byłych Marynarzy przybyli z ziemią „, g grobów poległych obrońców Ojczyzny z cmentarza Rossa w Wilnie", a ziemię stanisławowską przywieźli ułani kresowieccy ${ }^{133}$.

Uroczystość poświecenia Kopca wyzwolenia była bardzo starannie przygotowana zarówno od strony informacyjnej, organizacyjnej, jak i patriotycznej. Świadczą o tym opublikowane $w$ prasie instrukcje policji dotyczące ruchu kołowego i pieszego, urządzenie i rozmieszczenie parkingów, wzmocnienie łączności i dostępu do telefonów, sporządzenie specjalnego „datownika propagandowego", rozbudowa shużby sanitarnej w miejscu manifestacji i okolicy, bogaty prasowy serwis fotograficzny, a nawet produkcja pamiątek i - używając współczesnego określenia - gadżetów. Tuż przed poświęceniem Kopca Wyzwolenia, w piątek 18 czerwca, do Piekar via Mysłowice przybył pięcioosobowy patrol

${ }^{131}$ Ztota Księga zatożona z okazji budowy..., s. 6.

${ }^{132} \mathrm{PZ} 1935$, nr 260.

${ }^{133} \mathrm{Na}$ Górnym Śląsku istniały także organizacje społeczno-polityczne, które odnosily się do budowy Kopca Wyzwolenia w Piekarach, a szczególnie jego idei, niechętnie, a właściwie - wrogo. Skupiały one w swych szeregach nie tylko etnicznych Niemców, ale także Polaków stawiajacych na pierwszym planie bieżące interesy proletariatu. Należały tutaj: skrajnie nacjonalistyczna Deutsche Partei, nazistowska Jungdeutsche Partei für Polen Rudolfa Wiesnera z Bielska oraz Deutsche Sozialistische Partei Polen. Wyjątek wśród organizacji niemieckich stanowiła Deutsche Katholische Volkspartei, kontynuująca tradycje dawnej partii Centrum, która potrafila stawiać wysoko wartość wyznania, wyżej od innych, bieżacych idei związkowych. J. W a l c a k, Robotnicze drogi Śląka i Zagtębia Dąbrowskiego (do roku 1939), Katowice 1985, s. 191-294 
pieszy Związku Powstańców Śląskich ze Lwowa, który przyniósł urnę z ziemią pobraną na pobojowisku pod Zadwórzem ${ }^{134}$. Inna sztafeta przyniosła ziemię $\mathrm{z}$ pobojowiska $\mathrm{w}$ województwie łódzkim. Wszyscy przybyli podziwiali wiele tryumfalnych bram i dekoracje w całym mieście. Szczególnie imponowała ulica Mariacka, wzdłuż której ustawiono długi szereg wysokich masztów z chorągwiami i godłami państwowym ${ }^{135}$. W wigilię uroczystości młodzież wieczorem rozpaliła olbrzymie ognisko na Kopcu, czerpiąc ogień ze zniczy przywiezionych przez sztafety rajdu motocyklowego Zwiazku Powstańców Polski z pobojowisk całej Polski, pomników poległych powstańców z wszystkich powiatów województwa śląskiego, Kopców Marszałka Józefa Piłsudskiego i Tadeusza Kościuszki w Krakowie oraz Unii Lubelskiej we Lwowie. O tej samej porze, na głos dzwonów kościelnych, wszyscy obywatele Piekar i okolicy rozpoczęli iluminacje okien, łącznie z oknami wystawowymi. Pod kopcem Wyzwolenia Śląska rozpoczęły się liczne zawody sportowe i zabawy ludowe ${ }^{136}$.

Uroczystość poświęcenia Kopca Wyzwolenia - „widomego znaku wolności narodowej”, „symbolu nadziei”, „znaku harmonii z całym narodem polskim" odbyła się w zaplanowanym terminie, tj. w niedzielę 20 czerwca 1937 ro$\mathrm{ku}^{137}$. Mimo niezbyt sprzyjającej pogody, pod Kopcem Wyzwolenia i w jego najbliższej okolicy miała miejsce największa w dziejach Piekar i najbardziej podniosła manifestacja narodowa. Obok wielu dziesiątek organizacji półwojskowych i społecznych przybyłych ze sztandarami, Kopiec otoczyły zwarte oddziały wojskowe w pełnym rynsztunku bojowym ${ }^{138}$. Na ścieżkach prowadzących na szczyt Kopca ustawiły się delegacje ze sztandarami. U podnóża Kopca Wyzwolenia, bliżej ołtarza zajęli miejsca: wicepremier E. Kwiatkowski, wojewoda M. Grażyński, marszałek Sejmu Śląskiego K. Grzesik, wicewojewoda R. Saloni, pułkownik R. Sadowski, liczni senatorowie, posłowie, naczelnicy wydziałów Śląskiego Urzędu Wojewódzkiego, starostowie powiatowi, prezydenci miast, naczelnicy gmin i inni urzędnicy państwowi ${ }^{139}$. Tysiące uczestników przybyło na motocyklach i chłopskich wozach. „Niezliczone rzesze społeczeństwa stały karnie", zachowując wzorowy porządek. Na początku uwaga zebranych koncentrowała się na ołtarzu polowym z obrazem Matki Bożej Piekarskiej, gdzie Mszę św. celebrował biskup polowy Wojska Polskiego J. Gawlina, który również wygłosił kazanie ${ }^{140}$.

${ }^{134}$ W skład patrolu, który w ciagu 15 dni przeszedł droge długości 439 km, wchodzili uczestnicy trzech powstań ślasskich: Karol Zdebelak, Andrzej Czerny, Jan Cwajno, Jan Patecki i Antoni Mielczarek. - PZ 1937, nr 167.

${ }^{135} \mathrm{PZ} 1937$, nr 178.

${ }^{136}$ PWP 1937, nr 25.

${ }^{137}$ Tamże.

${ }^{138} \mathrm{PZ} 1937, \mathrm{nr} 171$

${ }^{139}$ GN 1937, nr 26.

${ }^{140}$ Biskupowi towarzyszyło 200 księży. 
„Przez czas 600 letniej niewoli - mówił ks. biskup - lud śląski nie utracił ani mowy polskiej, ani miłości ku Ojczyźnie. A gdy było potrzeba, oddawał życie swoje i przelewał krew swoją za wolność, za Polskę. A z ofiary krwi wyrosła diecezja śląska, która dała Kościołowi kardynała Prymasa i 5 biskupów. Ślązak, choć go się powszechnie uważa za materialistę, jest na wskroś idealista, a ideałem jego jest Bóg i Ojczyzna. Chociaż wiara św. spotyka się dziś z prześladowaniem w niektórych krajach Europy, niech z tego Kopca sztandar Chrystusa Króla, wraz ze sztandarem Orła Białego głoszą całemu światu, że Macierz nasza, Polska, jest matką katolicką" "141. Po kazaniu ks. bp Gawlina poświęcił Kopiec Wyzwolenia. Podczas tej ceremonii w chmury wzbiły się tysiące gołębi. Artyleria oddała salwy honorowe. Po odegraniu hymnu narodowego na komendę płk. Sadowskiego, który zwrócił się do żołnierzy słowami: „Aby zadokumentować ludności Sląska, że JESTEŚCIE GOTOWI W KAZZDEJ CHWILI DO OBRONY JEJ SWOBÓD I WOLNOŚCI I JEJ POKOJOWEJ PRACY, razem ze mną wznieście okrzyk: «Polski na wieczne czasy Śląsk niech żyje»". Następnie przybyli dostojnicy podpisali dokument poświęcenia Kopca ${ }^{142}$. Udokumentowano w nim:

„Działo się to w Piekarach Śląskich, dnia 20 czerwca 1937 roku, kiedy z inicjatywy Związku Powstańców Ślaskich na trwały znak wiekowych zmagań polskiego ludu śląskiego, uwieńczony wolnością prastarej Ziemi Piastowskiej, ku uczczeniu pamięci poległych bohaterów nad brzegami Odry i pod Góra Św. Anny, w rocznicę piętnastolecia przyłączenia części Gómego Śląska do Polski usypano Kopiec ten o łącznej kubaturze 28600 metrów sześciennych, 20 metrów wysoki, o średnicy podstawowej [ma być :podstawy] 67,70 m i szczytowej 6 metrów, usypany na Wzgórzu «Rodzińska Góra» 336 metrów nad poziomem morza. W Kopcu znajduje się ziemia ze wszystkich działań Rzeczypospolitej, uświęconych tradycją historyczna narodu polskiego i zroszonych krwią poległych legionistów, powstańców i żołnierzy polskich, m.in. z mogił powstańców Śląska Opolskiego i Czeskiego, z pól bitew powstań narodowych z roku 1831 i 1863, z grobów polskich wieszczów pozostałych za kordonem, jak ks. Norberta Bonczyka w Bytomiu, ks. Józefa Szafranka w Bytomiu, ks. Konstantego Damrota w Pilchowicach, $\mathrm{z}$ grobów zmarłych i poległych powstańców i działaczy narodowych spoczywających na ziemi śląskiej, oraz z Kopców Tadeusza Kościuszki w Krakowie, Unii lubelskiej we Lwowie i Pierwszego marszałka Polski J. Piłsudskiego na Sowińcu. Kopiec Wyzwolenia usypany został rękami ludu polskiego, a w dniu dzisiejszym pod wysokim protektoratem Premiera gen. Sławoj - Składkowskiego poświęcony.

Kopiec Wyzwolenia niech po wszystkie czasy stanowi widomy znak bohaterskich i zwycięskich czynów ludu śląskiego i jego wierności Ojczyźnie. Niechaj braciom naszym zza kordonu, których serca polskie, biją jednym rytmem z naszymi ${ }^{143}$.

141 PWP 1937, nr 26; GN 1937, nr 26.

${ }^{142}$ Według informacji uzyskanej w dn. 17. 06. 1994 r. od pracownika Urzędu Miejskiego w Piekarach Śl., oryginału dokumentu Poświęcenia Kopea Wyzwolenia nie udało się odnaleźć, ponieważ „zawieruszył się”. W niniejszej pracy podaje się jego streszczenie, cyt. za „Polską Zachodnią".

${ }^{143} \mathrm{PZ} 1937, \mathrm{nr} 168$. 
Podczas wzniosłych uroczystości przemówienia wygłosili wojewoda $\mathrm{M}$. Grażyński, którego wystapienie eksponowała prasa na Górnym Śląsku, oraz wicepremier E. Kwiatkowski.

Wojewoda śląski, będący uczestnikiem II powstania śląskiego i zwolennikiem kontynuowania walki zbrojnej wbrew koncepcjom W. Korfantego, okres od wkroczenia Wojsk Polskich na teren Śląska w czerwcu 1922 roku do momentu poświęcenia Kopca Wyzwolenia nazwał „cudem odwiecznych marzeń”. Jako honorowy przewodniczący Związku Powstańców Śląskich przypomniał też zebranym słowa pierwszego wojewody śląskiego Józefa Rymera, który podkreślił dumę społeczeństwa $\mathrm{z}$ polskiej armii dzielnie broniącej - jak niegdyś rycerze Bolesława Chrobrego i Bolesława Krzywoustego - zachodnich granic państwa. Przedstawił fakt odzyskania wolności Polski nie tylko zabiegami dyplomatycznymi, ale „własnym żołnierskim czynem”, który „kontynuuje rycerską tradycję polskiego ludu", dzięki czemu społeczeństwo potrafiło „w najcięższych warunkach obronić swoją duszę narodową". W przemówieniu potwierdził również, że „chce utrwalić w psychice tutejszego społeczeństwa najwyższe wartości tradycji powstańczej, przejawiające się w rzetelnej służbie Ojczyźnie". Jako zwolennik i realizator częściowej etatyzacji przemysłu na Śląsku Grażyński pragną „na tej tradycji oprzeć nie tylko szlachetnie pojętą dumę narodową tutejszego społeczeństwa, ale i wolę solidarnej pracy ze wszystkimi Polakami pod hasłem tworzenia prawdziwej potęgi narodu i państwa"144.

Przedstawiciel rządu RP, wicepremier E. Kwiatkowski, ograniczył swoje przemówienie do analizy treści dwóch „symbolicznych i ofiarnych słów” umieszczonych na wojskowych sztandarach polskich: „Honor i Ojczyzna”. Zajmując równocześnie stanowisko ministra skarbu, Kwiatkowski duży nacisk kładł na „nakręcenie" koniunktury w Polsce przez rozbudowę przemysłu ze środków państwa i samorządów. Dlatego, jego zdaniem. „Honor oznacza prawo umierania za wolność, a Ojczyzna - to trwały trud w pracy dla Państwa i Narodu"145. Zaznaczył, że treść tych haseł zrealizowano na Śląsku, dzięki czemu został on wyzwolony, a pozytywne skutki wyzwolenia są dla wszystkich widoczne ${ }^{146}$.

Pamiętną uroczystość dopełniło poświęcenie nowej szkoły im. Marszałka Piłsudskiego przez miejscowego proboszcza ks. W. Puchera.

Chociaż pod Kopcem Wyzwolenia padały zapewnienia ze strony przedstawicieli władz, iż społeczeństwo Śląska zebrane w Piekarach nie tylko tworzy „wspaniałą manifestację uczuć narodowych”, a „Rząd Rzeczypospolitej Polskiej... w harmonii z całym narodem polskim „składa hołd i cześć tym wszystkim znanym i nieznanym bohaterom, którzy w ciągu całych pokolen, w ciagu całych dziesięcioleci i wieków prowadzili Śląsk ku Polsce", to w tym samym czasie na Polach Mokotowskich w Warszawie odbywał się Kongres Centralnego Zwiazku Młodej Wsi z udziałem premiera gen. F. Sławoj-Składkowskiego, marszałka E. Śmigłego Rydza i kilku członków rządu: m. in. ministrów M. Kościałkowskiego, gen. T. Kasprzyckiego, J. Poniatowskiego i W. Grabowskiego, wicemarszał-

\footnotetext{
${ }^{144}$ Tamże.

${ }^{145}$ Tamże.

${ }^{146}$ Tamże.
} 
ka Sejmu S. Kielaka oraz innych dostojników państwowych ${ }^{147}$. Czy świadczyło to, że rząd RP przywiazzuje do Kongresu większą wage polityczną niż do wydarzeń na Śląsu? Dwa miesiące później na Śląsku gościła liczna grupa posłów i senatorów RP. W czasie trzydniowej wycieczki parlamentarzyści zwiedzali ważniejsze ośrodki przemysłowe, przejeżdżali też przez Piekary. Kopca Wyzwolenia jednak nie zwiedzili. Wielu Ślązaków oceniło ów fakt w kategoriach niefrasobliwości i nieudolności władzy ${ }^{148}$, która nie potrafiła dostrzec wzrastającego zagrożenia ze strony niemieckiego szowinizmu, którego zwiastunem od 1936 roku był ponowny wzrost antypolskiej kampanii rewizjonistycznej w Rze$\mathrm{szy}^{149}$. Wydarzenie to nie ułatwiało więc już i tak niezwykle trudnej polityki polskiej na tym terenie.

Budowa Kopca Wyzwolenia w Piekarach koło Bytomia trwała dłużej niż usypywanie Kopca Kościuszki w Krakowie ${ }^{150}$. Była jednym ze spektakularnych efektów przyswajania sobie dziedzictwa polskiej kultury narodowej i polskiej tradycji przez społeczeństwo Górnego Śląska. Długi okres przygotowawczy owego procesu przyswajania, podczas którego narastała polska świadomość narodowa społeczeństwa przygotowywanego przez wielu przywódców duchowych i kilka pokoleń, był konieczny. Tryptyk powstań śląskich i plebiscytu miał zasadnicze znaczenie dla budowy Kopca Wyzwolenia, gdyż nie tylko przeciwstawiał się kilkuwiekowej akcji germanizacyjnej, ale zmierzał do oderwania Górnego Śląska od Niemiec i Prus po to, by zjednoczyć górnośląskich Polaków $\mathrm{z}$ całym narodem polskim $\mathrm{w}$ ramach państwa polskiego. Podział obszaru plebiscytowego w roku 1922 sztucznie dzielił bowiem jednolity dotąd organizm, stanowiący całość $\mathrm{z}$ historycznego, administracyjnego, etnicznego i gospodarczego punktu widzenia ${ }^{151}$. Potwierdza to najnowsza historiografia niemiecka ${ }^{152}$. Wytyczona granica była nowa, miała charakter irracjonalny i tymczasowy. Obie strony, polska i niemiecka, miały zatem powód do manifestowania niezadowolenia ze sposobu jej wytyczenia ${ }^{153}$. Granica między świadomością narodową Polaków i Niemców na Górnym Śląsku stawała się coraz bardziej ostra i wyraźna. Pociągała za sobą postawę widoczną w życiu jednostki i społeczeństwa nie tylko w akcjach wyborczych, deklaracjach przynależności do określonych stowarzyszeń, ale także w czynnym udziale w pracy społecznej po każdej ze zwalczających się stron. Pozostaje paradoksem, że funkcjonowanie Kopca Wyzwolenia we współczesnym życiu społeczno-politycznym Piekar Śląskich i województwa katowickiego stoi przed tym samym wyzwaniem.

147 Tamże.

${ }^{148}$ Kronika parafii Najświętszej Maryi Panny w Piekarach Śl. (od 16.11. 1935 r. do 31.12. 1965), rkp., bez sygn., wklejka po s. 132.

${ }^{149}$ W styczniu 1936 r. hitlerowski minister gospodarki Hjalmar Schacht publicznie wyraził w Bytomiu nadzieje na powrót Górnego Śląska do Niemiec, co z niepokojem śledziła polska ludność w obu częśsiach podzielonego Śląska.

${ }^{150}$ Kopiec Kościuszki budowano 3 lata.

151 J. M a c ała, Duszpasterstwo a narodowość wiernych. Kościót katolicki w diecezji katowickiej wobec mniejszości niemieckiej 1922-1939, Wrocław-Katowice 1999, s. 8 n.

${ }^{152}$ J. B a h 1 c ke , Ślqask i Ślqzacy, Warszawa 2001, s. 173 n.

${ }^{153}$ G. L a b u d a, Polska granica zachodnia, Poznań 1971, s. 148 i ns. 